\title{
SEJARAH LEMBAGA PENDIDIKAN KHUSUS TUNAGRAHITA DI JAWA
}

\section{Mumpuniarti \\ FIP Universitas Negeri Yogyakarta (email: nmumpuniarti@yahoo.com)}

\begin{abstract}
Abstrak: Sejarah Lembaga Pendidikan Khusus Tunagrahita Di jawa. Penelitian ini bertujuan untuk merefleksi kausalitas dan masalah utama dalam mendirikan lembaga untuk siswa dengan keterbelakangan mental. Penelitian ini menggunakan pendekatan kualitatif dengan metode historis dan reflektifinterpretatif. Hal ini dilakukan dalam tahap berikut: tahap pengumpulan sumber, tahap pengelompokkan sumber dan ke tahap sumber penting. Tahap analisis dilakukan dengan basis interpretatif mengenai implikasi dari sumber dan menjelaskan tema dasar pada kausalitas dan masalah utama. Temuan berikut menunjukkan perkembangan Lembaga pendidikan bagi siswa dengan keterbelakangan mental di Jawa dalam memecahkan masalah pembelajaran terhadap siswa di sekolah dasar dan ditangani melalui program khusus untuk siswa dengan keterbelakangan mental. Masalah utama yang berkelanjutan pada institusi khusus untuk siswa dengan keterbelakangan mental adalah implementasi program khusus dengan program keahlian.
\end{abstract}

Kata Kunci: sejarah, institusi pendidikan khusus, keterbelakangan mental

\begin{abstract}
Historical of Institution for Education of Mentally Retarded. This study aims to reflec of causality and main's problem to stand of institution for mentally retarded. This study employed the qualitative approach with historical method and reflective-interpretative. It was conducted in following stages: the sources collecting stage, categorizing sources and to critical sources stage. The analysis stage to conduct with interpretatif base on implication of the sources and to explain of theme base on causality and main problems. The following findings show the development of Institution of education for mentally retarded students in Java in solving of learning problems of student in elementary school and to carry out the special programs for special needs for mentally retarded students. The main sustainable problem for special institution for mentally retarded student is the implementation of special program with skill program.
\end{abstract}

Keywords: history, special education institution, mentally retarded 


\section{PENDAHULUAN}

Pengkajian sejarah dikemukakan oleh Jakob Burckhardt dalam Thoughts on World History (Cassirer, 1990:261) untuk mengetahui dengan pasti unsur-unsur konstan yang selalu berulang dan tipikal. Unsur-unsur konstan tentang kebutuhan sebuah lembaga khusus bagi tunagrahita sebagai usaha mempertahankan perlunya lembaga itu di tengah-tengah masyarakat. Lembaga khusus bagi pendidikan tunagrahita merupakan upaya yang dilakukan sebagian masyarakat atau negara dalam menampung tunagrahita. Sebuah tempat penampungan ini difungsikan untuk mendidik mereka, namun juga ada yang dipergunakan sebagai tempat perawatan sepanjang hayat bagi tunagrahita.

Lembaga khusus yang berfungsi bagi pendidikan tunagrahita perlu dikaji eksistensinya di tengah masyarakat. Lembaga itu menjadi sebuah kebutuhan dan memiliki keberlangsungan dalam fungsi pendidikan, tidak lepas dari sejarah munculnya lembaga pendidikan khusus bagi tunagrahita. Lembaga tersebut sebagai sebuah kebutuhan yang perlu dipertahankan fungsinya karena memberi makna bagi yang membutuhkan. Kebutuhan sebuah lembaga pendidikan khusus bagi tunagrahita dan keberlangsungan dalam masyarakat juga sebuah refleksi dari kehadiran fungsi pendidikan khusus bagi tunagrahita. Untuk itu, sejarah lembaga khusus bagi tunagrahita perlu dikaji kembali dalam refleksi fungsi pendidikan bagi tunagrahita.
Kebutuhan lembaga khusus diperlukan oleh masyarakat untuk mendidik anak yang dianggap berkelainan/ cacat, termasuk penyandang tunagrahita. Lembaga khusus itu pada awalnya cenderung untuk perawatan permanen karena tunagrahita dipandang kecacatan yang permanen. Kecacatan itu tidak memungkinkan mereka untuk mandiri di masyarakat. Oleh karena itu, keberadaan lembaga khusus dibutuhkan untuk mengurangi masalah di masyarakat. Pergeseran zaman berimplikasi paradigma masyarakat dalam memandang potensi tunagrahita. Mereka masih mampu untuk dioptimalkan sehingga kebutuhan lembaga bergeser menjadi lembaga pendidikan sekaligus masih bertahan untuk perawatan dengan bentuk asrama. Keberlangsungan lembaga pendidikan khusus bagi tunagrahita tergantung kepentingan masyarakat. Kajian untuk keberlangsungan lembaga pendidikan bagi tunagrahita perlu ditentukan sesuai dengan paradigma masyarakat, terutama bagi para orang tua penyandang tunagrahita. Mereka yang berkaitan langsung memanfaatkan lembaga tersebut dalam mengupayakan masa depan anaknya yang mengalami ketunagrahitaan.

Pendidikan merupakan upaya sadar memanusiakan manusia dalam habitus kemanusiaan. Hal itu merujuk Tilaar (2005:110) yang mengatakan bahwa pendidikan "proses-menjadimanusia terjadi di dalam habitus kemanusiaan." Habitus kemanusiaan merupakan lingkungan alam dan budaya masyarakat. Habitus tersebut terdapat 
fenomena pendidikan. Fenomena tentang membantu potensi, perilaku, dan nilai peserta didik dalam kehidupan sehari-hari menuju kepada suatu tujuan yang dilakukan oleh pendidik. Tujuan untuk menjadi manusia sesuai dengan habitus kemanusiaan itulah yang perlu pengkajian kelembagaan, seperti halnya lembaga khusus pendidikan bagi tunagrahita.

Lembaga pendidikan khusus bagi tunagrahita sebagai respon terhadap pandangan penyimpangan dengan upaya menyendirikan tunagrahita di lembaga khusus. Lembaga itu dipandang sebagai solusi untuk merawat tunagrahita sepanjanghayatatau memberikan pendidikan secara khusus. Manusia yang berbudaya dalam masyarakat akan membentuk nilai yang menjadi norma budaya itu sendiri. Manusia yang dipandang tidak mampu secara budaya atau nilai budaya dilabel menyimpang. Label inilah yang menciptakan kontruks sosial bahwa penyandang cacat atau kelainan sebagai penyimpangan. Nilai berpengaruh terhadap label kelainan yang dikaitkan dengan budaya masyarakat. Hal itu dikemukakan Sunardi (1995:17) bahwa pengaruh label yang dimiliki seseorang merupakan akibat respon budaya terhadap perilakunya. Respon budaya inilah yang menimbulkan cultural diversity. Nilai cultural diversity itu juga digunakan untuk melabel penyandang tunagrahita sebagai anggota masyarakat yang menyimpang sehingga mereka perlu sebuah lembaga khusus untuk mengatasi kondisi penyimpangan tunagrahita.
Tunagrahita atau yang disebut mentally retarded menurut AAMR (Association American Mental Retardation) yang disampaikan oleh Ruth Luckasson (Smith, et.all., 2002:50; Wehmeyer, et.all., 2008:21) sebagai berikut.

"Mental retardation "refers to substantial limitations in present functioning. It is characterized by significantly subaverage intellectual functioning, existing concurrently with related limitations in two or more of the following applicable adaptive skill areas: communication, self-care, home living, social skills, community use, selfdirection, health and safety, functional academics, leisure and work. Mental retardation manifests before age 18."

Definisi dari AAMR tersebut yang sekarang menjadi dasar untuk petunjuk atau identifikasi pada individu yang dianggap kategori retardasi mental atau tunagrahita. Individu dianggap terbelakang mental jika memenuhi dua kriteria yang dikemukakan oleh AAMR. Keterbelakangan atau kekurangan dalam adaptasi tingkah laku dan kekurangan penyesuaian diri dengan lingkungannya diukur dengan taraf usia menurut kalender yang telah dicapai seorang anak. Itulah yang menjadi penekanan berbagai definisitentang anak terbelakang mental atau tunagrahita. Keterbelakangan tersebut meliputi 10 bidang keterampilan adaptif, yaitu: komunikasi, menolong diri sendiri, keterampilan kehidupan di keluarga, keterampilan sosial, kebiasaan di masyarakat, pengarahan diri, menjaga kesehatan dan keamanan diri, akademik fungsional, waktu luang dan kerja. 
Pendidikan khusus bagi tunagrahita berupa pemberian program khusus dan program pendidikan lainnya agar tunagrahita mampu beradaptasi di masyarakat secara budaya. Tunagrahita sebagai individu bagian dari masyarakat juga memerlukan berkembang menuju manusia dalam habitus kemanusiaan. Hambatan perkembangan yang ada pada tunagrahita perlu program khusus, dan intensitas program itu diselenggarakan di lembaga pendidikan khusus. Dalam konteks optimalisasi pendidikan bagi tunagrahita inilah perlunya lembaga khusus bagi tunagrahita.

Tugas kajian historis dalam ilmu pendidikan dikemukakan Barnadib (1982:12-13) yang mengungkapkan bahwa pendidikan yang dilakukan di masa lampau yang mengandung gagasan tertentu. Gagasan itu menjadi sumbangan bagi perkembangan ilmu pendidikan sistematis. Gagasan yang diungkap termasuk landasan yang digunakan. Hal ini mendasari pengkajian gagasan perlunya pendidikan bagi tunagrahita dengan model kelembagaan secara khusus. Gagasan masa lampau tentang perlunya lembaga khusus bagi tunagrahita adalah sebuah refleksi untuk keberlangsungan pendidikan khusus bagi tunagrahita.

Gagasan masa lampau tentang mengupayakan pendidikan khusus bagi penyandang tunagrahita/terbelakang mental merupakan kontribusi terhadap perkembangan pendidikan khusus. Esensi pendidikan khusus bagi tunagrahita hadir dan mampu berlangsung dalam perubahan zaman sebagai dasar pendidikan khusus bagi tunagrahita. Esensi tersebut perlu dikembangkan lebih baik dan lebih maju sesuai dengan teori sejarah pendidikan yang dikemukakan Roeslan Abdulgani (Barnadib, 1982:26), bahwa untuk memilih pandangan mengenai sejarah pendidikan hendaklah yang dapat dipergunakan sebagai "teleskop" atau alat teropong ke masa depan. Kepercayaan akan kehendak Illahi Yang Maha Esa tetap menjadi pedoman, namun selalu berusaha untuk maju terus. Pandangan progresif ini tetap meyakini hal-hal masa lampau selalu berulang, tetapi ulangan berikutnya ke arah meningkat lebih tinggi dan maju.

Kelembagaan bagi tunagrahita muncul yang di masa lalu tidak lepas bersumber dari pandangan masyarakat terhadap tunagrahita. Tunagrahita di masa lalu dipandang sebagai makhluk yang aneh yang perlu disendirikan dari masyarakat. Perkembangan masyarakat menentukan juga perlakuan terhadap tunagrahita, bahwa tunagrahita yang hidup di masyarakat bersifat agraris tidak menjadikan problem di masyarakat, namun perubahan ke arah masyarakat yang kompleks adanya tunagrahita menjadikan problem bagi masyarakat. Hal itu dikemukakan oleh Drew, Logan, dan Hardman (1986:50), "Before 1800, with a few notable exceptions, the mentally retarded were not considered to be an overriding social problem in any society. This is because the more severely retarded either were killed or died of natural causes at an early age. Those who today we would term mildly retarded were usually 
sufficiently able to contribute to an agrarian society in a meaningful way."

Dalam cerita di atas, disebutkan bahwa sebelum tahun 1800 , penyandang tunagrahita atau mental retardasi tidak dipertimbangkan sebagai sebuah problem masyarakat yang memberatkan. Hal ini disebabkan penyandang yang retardasinya berat secara alami meninggal di awal kehidupannya. Bagi penyandang yang retardasi ringan cukup mampu berkontribusi pada masyarakat agraris dengan cara yang bermakna. Riwayat tersebut mengasumsikan bahwa tunagrahita sebagai problem di masyarakat tergantung kondisi perkembangan masyarakat. Bagi tunagrahita ringan, mampu berkontribusi pada masyarakat yang sederhana seperti masyarakat yang agraris, bagi yang tunagrahita yang berat karena kondisinya yang secara fisik juga lemah secara alami tidak berumur panjang.

Dalam perkembangan masyarakat selanjutnya, tunagrahita sebagai sebuah beban yang ada di masyarakat. Beban itu juga terkait pada tunagrahita di kehidupan masa dewasa. Pada masa dewasa, mereka diragukan kemampuannya untuk bertanggung jawab dalam berkeluarga. Untuk itu, Drew, Logan, dan Hardman (1986: 52) meriwayatkan: "Because of the fear of mental retardation, support for controlling methods such as sterilization and incarceration became relatively widespread. The result was an almost immediate and virtual destruction of special schools in some states. The purpose of the schools now became custodial care to prevent reproduction. This represented a consider- able philosophical shift; since there had previously been at least guarded optimism that institutions would be able to provide education and training for their retarded inmates. Societal fears therefore have influenced the nature, role, and function of such institutions in society."

Menurut riwayat tersebut, lembaga bagi tunagrahita diperuntukkan tempat perawatan dan pencegahan reproduksi. Tujuan itu menjadi mengemuka karena rasa optimis yang sedikit terhadap peranan lembaga yang mampu menyediakan pendidikan dan latihan bagi orang retardasi penghuni lembaga. Ketakutan masyarakat berpengaruh terhadap sifat, peranan, dan fungsi lembaga-lembaga perawatan bagi tunagrahita di masyarakat. Tujuan yang diperuntukkan perawatan dan pencegahan reproduksi menjadkan lembaga bagi orang-orang retardasi atau tunagrahita sebagai tempat perawatan atau asrama yang permanen. Mulai fenomena ini lembaga bagi tunagrahita sebagai institutionalization dan sterilization dengan melakukan perawatan pada tunagrahita sepanjang hidup.

Perkembangan kelembagaan untuk anak yang dipandang tunagrahita di Indonesia menurut Suparlan (1983: 69) lebih banyak muncul sejak diadakannya Seminar untuk Kesejahteraan Penderita Cacat Mental tahun 1967 di Yogyakarta. Demikian juga, programnya berorientasi keterampilan. Hal tersebut juga dikemukakan oleh John Langlo dan Kevin (Astati, 2001:16) bahwa inti kurikulum sekolah menengah bagi tunagrahita ialah pendidikan keterampilan yang mengarah- 
kan pada pekerjaan. Keterampilan sebagai program yang mensejarah dalam kelembagaan bagi tunagrahita juga atas dasar ide dari Alice Channing dan Marcella E. Douglas di tahun 1940 dengan istilah Occupational Education (Suparlan, 1983:21).

\section{METODE}

Sumber sejarah dari penelitian ini berasal dari dokumen tertulis berupa buku-buku dari kenangan yang disusun oleh lembaga-lembaga pendidikan tunagrahita. Buku-buku yang ditulis oleh Suparlan diterbitkan oleh Pustaka Pelajar Yogyakarta tahun 1983, serta hasil wawancara dengan kepala sekolah dan orang tua penyandang tunagrahita di lembaga pendidikan khusus tunagrahita. Pemilihan sumber dipilih pada sekolah khusus tunagrahita yang paling tertua berdiri di Daerah Istimewa Yogyakarta.

Hasil dokumen dan wawancara dipilih setelah dilakukan kritik sumber atas dasar sifat atau atribut sumber. Kritik eksternal atas dasar otentitas sumber informasi yang terdapat pada sumber, sedangkan kritik internal atas dasar arti dan kebenaran pada isi dari sumber. Analisis dilakukan penafsiran atas dasar isi pesan yang tersirat dari sumber, dan penjelasan tematik sebagai sintesis atas dasar kausalitas dan pokok persoalan untuk disajikan sebagai ceritera sejarah (historiografi).

\section{HASIL DAN PEMBAHASAN}

Hasil penelitian dipaparkan atas dasar tema kausalitas dan pokok persoalan adanya lembaga pendidikan khusus bagi tunagrahita di Jawa. Paparan itu menunjukkan suatu refleksi kepentingan lembaga pendidikan khusus bagi tunagrahita di tengah masyarakat. Lembaga-lembaga tersebut difokuskan pada peristiwa sesudah Indonesia merdeka.

\section{Kausalitas di Wilayah Jakarta}

Lembaga 'Asih Budi' dianggap sebagai lembaga pendidikan bagi tunagrahita di Jakarta atas dasar pernyataan tertulis yang bersumber dari sebuah buku kenangan 40 tahun perjalanan 'Asih Budi'. Beberapa sumber tertulis tentang perjalanan 'Asih Budi' terdapat dari berbagai tulisan orangorang kunci yang membina yayasan tersebut, dan telah dihimpun dalam suatu buku kenangan saat merayakan ulang tahun ke-41. Buku itu berjudul "Asih Mengasah \& Mengasuh Budi" dalam rangka menjelaskan perjalanan 40 tahun (mulai 1957 sampai dengan 1997) memberdayakan penyandang tunagrahita. Asih Budi sebagai kategori perintis pertama sekolah khusus tunagrahita di Jakarta didapatkan dari tulisan pengantar pada buku tersebut di halaman xiii, sebagai berikut.

“Dalam buku ini kami persembahkan kisah sebuah sekolah yang didirikan oleh seorang ibu yang menyesalkan, bahwa putranya tidak diberikan kesempatan untuk bertumbuh kembang. Putranya adalah Achmad Soerjomihardjo yang gugur dalam revolusi melawan tentara Belanda. Ibunya ingin memberikan kesempatan ini kepada sebagian putra-putri Indonesia yang mungkin diabaikan oleh orang tua 
mereka karena tidak mengetahui cara bagaimana mendidik putraputri mereka.

Siapakah Ibu yang luar biasa ini? Ia adalah almarhumah ibu Hisnat Soerjomihardjo dan sekolah yang didirikannya adalah sekolah Asih Budi yang di masa itu merupakan sekolah satu-satunya untuk anak-anak tunagrahita di Jakarta. Sekolah ini didirikan dengan modal Rp. 100,-."

(Sumber dari buku kenangan 40 tahun 'Asih Budi' yang diberi judul

"Asih Mengasah \& Mengasuh Budi")

Pada tulisan paragraf baris akhir dari paragraf pertama disebutkan bahwa tujuan mendirikan sekolah adalah untuk mendidik sebagian putra-putri Indonesia yang diabaikan oleh orang tua mereka karena tidak mengetahui cara mendidiknya. Pada saat tersebut, yaitu saat perlunya dirintis sekolah khusus bagi tunagrahita, kondisi masih kurangnya perhatian terhadap tunagrahita. Hal tersebut juga diperkuat oleh pernyataan ilustrasi pokok dari buku riwayat perjalanan yayasan Asih Budi, berikut:

"Pada tahun limapuluhan berbagai penyandang cacat telah mendapat perhatian khusus dari pemerintah maupun dari fihak swasta. Namun, ada satu golongan penyandang cacat yang masih kurang diperhatikan, ialah penyandang tunagrahita".

Kondisi saat tahun lima puluhan (kurang lebih lima tahun sesudah Indonesia Merdeka) belum banyak perhatian kepada penyandang tunagra- hita dikarenakan sebagian para penyandang tunagrahita menampakkan fisik yang normal. Mereka baru terlihat perlu perhatian khusus ketika harus mengikuti proses belajar, terutama belajar yang bersifat akademis. Pernyataan tersebut juga didapatkan pada riwayat mulainya ide didirikan sebuah yayasan 'Asih Budi'. Demikian juga beberapa sumber tertulis lain yang memperkuat bahwa saat tahun lima puluhan belum banyak perhatian kepada penyandang tunagrahita. Secara berturut-turut dapat dituturkan sebagai berikut.

Sumber yang berasal dari tulisan Pia Alisyahbana-Soerjomihardjo seorang puteri pendiri Asih Budi. Tulisan itu mengenai Asal Mula sekolah Asih Budi di halaman 3-4 diceritakan sebagai berikut.

"Sering kali kenalan-kenalan Ibu datang membawa putera-puterinya, yang mengalami kesulitan belajar di sekolah untuk mendapat pelajaran ekstra pada Ibu. Ketika itu—tahun 1950-kami tinggal di pojok Pegangsaan Timur dan Jalan Diponegoro, sekarang dikenal sebagai Jalan Proklamasi. Rumah tinggal itu sudah tidak ada, tetapi telah direnovasi menjadi sebuah bank. Di sanalah, di meja makan kami yang bulat, ibu memberi pelajaran-pelajarantambahan. Ibu mulai mengajar seorang anak perempuan berumur 9 tahun. Baik ibunya maupun gurunya sudah putus asa dengan anak ini. Selama empat bulan Ibu mengajarnya di rumah. Ternyata kesulitannya adalah tidak dapat konsentrasi. Setelah 4 bulan murid ini sudah dapat mengikuti pelajaran di sekolahnya dan setelah 
tamat SD dia melanjutkan ke sekolah lanjutan keterampilan, kemudian membantu ibunya di rumah.

Ternyata, banyak di antara anak-anak itu yang datang, tidak hanya mengalami kesulitan belajar mengikuti irama kelas normal, tetapi memerlukan perhatian khusus. Saya masih ingat, pada tahun 1953, salah seorang muridnya, ketika itu berumur 6 tahun, setiap kali disuruh menghitung, jawabnya selalu: "Selompret!". Ternyata anak ini menderita cacat mental berat. Ibu mulai sadar bahwa dengan les tambahan anak-anak semacam ini tidak dapat dibantu. Mereka memerlukan pendidikan khusus. Di antara mereka ada yang slow learner (lamban belajar), tetapi ada juga anakanak yang mentally retarded (cacat mental). Mereka ini adalah anakanak tunagrahita. Kebanyakan dari mereka dapat mengikuti pendidikan sekolah dasar, tetapi dengan amat lamban. Setiap kelas harus diulangi sehingga anak-anak merasa rendah diri. Ibu yakin bahwa mereka dengan pendidikan khusus bisa menjadi manusia yang berguna bagi masyarakat."

(Sumber tertulis penuturan Pia Alisyahbana putri tunggal perintis

'Asih Budi' yang meriwayatkan lahirnya 'Asih Budi')

Beberapa pernyataan di atas ditafsirkan bahwa untuk anak-anak yang memerlukan perhatian khusus dengan masalah kesulitan belajar di sekolah atau tidak mampu mengikuti irama belajar di sekolah normal belum mendapat perhatian khusus. Seperti pernyataan bahwa yang dinaungi oleh Yayasan Anak-Anak Cacat adalah khusus cacat jasmani, bukan yang cacat rohani. Hal ini menunjukkan bahwa anak tunagrahita belum diperhatikan.

\section{Pokok Persoalan Perlunya Lembaga Pendidikan Khusus bagi Tunagrahita}

Alasan-alasan bahwa pada tahun lima puluhan tunagrahita belum banyak diperhatikan inilah yang menjadi persoalan perlunya didirikan sebuah lembaga yang memperhatikan tunagrahita. Sumber tersebut berasal dari tulisan Y.B. Suparlan dalam bukunyaPengantar Pendidikan Mental Subnormal. Dalam buku tersebut, tunagrahita disebut dengan 'Mental Subnormal', dengan pertimbangan penggunaan istilah yang lebih halus. Mereka yang tunagrahita termasuk kategori penyandang yang memiliki mental di bawah normal/subnormal. Beberapa pernyataan tertulis tersebut, dikemukakan pada halaman 73 dari buku itu sebagai berikut.

"Keadaananak-anakmentalsubnormal jauh sebelum Masa Perintisan agaknya tidak mendapat perhatian masyarakat dan Pemerintah. Mereka menjadi tanggung jawab keluarga mereka masing-masing. Ada yang mendapat perhatian penuh dari keluarga, tetapi juga banyak yang 'terlantar' atau diabaikan saja. Berbagai hal yang menjadi sebab, misalnya karena keluarga tidak tahu cara menangani dan anak mental subnormal tidak dipandang sebagai masalah, baik oleh keluarga maupun oleh pemerintah jajahan. Kemudian lahir badan-badan swasta yang bekerja untuk kesejahteraan anak-anak mental subnormal, karena pemerintah kolonial 
tidak mau mengambil tanggung jawab di dalam masalah ini".

(Sumber dari perkembangan pendidikan anak mental subnormal di Indonesia yang terdapat pada buku Y B. Suparlan dengan judul Pengantar Pendidikan Anak Mental Subnormal).

Menurut Suparlan, yang dianggap masa perintisan adalah masa sebelum diadakan seminar pada tahun 1967. Masa sebelum itu dipandang sebagai masa perintisan karena seperti beberapa pernyataan yang terdapat pada halaman 70 dari buku tersebut. "Pengaruh Seminar itu dalam sejarah pendidikan cacat mental di Indonesia. Tidak berlebihan kiranya, apabila Seminar 1967 digunakan sebagai tonggak pembatasan antara dua periode, periode lama dan periode baru." (Sumber dari perkembangan pendidikan anak mental subnormal di Indonesia yang terdapat pada buku Y B. Suparlan dengan judul Pengantar Pendidikan Anak Mental Subnormal).

Berdasarkan pernyataan yang ditulis Y.B. Suparlan bahwa masa sebelum tahun 1967 (masa perintisan) menguatkan pada saat sekitar tahun lima puluhan (lima tahun sesudah kemerdekaan) belum banyak perhatian kepada penyandang tunagrahita. Untuk itu, pada tahun 1957 ketika berdirinya yayasan 'Asih Budi' di Jakarta, dianggap sebagai perintis pertama untuk pendidikan bagi tunagrahita pada wilayah Jakarta. Riwayat berdirinya 'Asih Budi' dan perkembangannya juga dituturkan secara tertulis oleh satu-satunya puteri pendiri yayasan tersebut sebagai berikut.
"Ketika itu saya masih mahasiswa pada Fakultas Sastra Universitas Indonesia, saya senantiasa membantu Ibu dengan administrasinya. Sebagai Kepala Sekolah menurut saya, Ibu melakukan manajemennya by instinct. Tidak ada konsep mengenai pendidikan dan tidak ada rencana khusus. Ibu mengambil keputusan sesuai dengan pandangannya dan pengalamannya sebagai guru. Misalnya Ibu memberikan pelajaran kepada anak-anak sesuai dengan kemampuan mereka, tidak sesuai dengan usianya seperti lazimnya di sekolah biasa. Mata pelajaran pun tidak sesuai dengan kurikulum resmi, sehingga misalnya ada anak yang diberi pelajaran berhitung menurut kelas 2 sedangkan bahasa menurut kelas 4, karena anak itu sukar menangkap pelajaran berhitung. Pun ada murid yang mendapat pelajaran bahasa menurut kelas 3 sedangkan berhitung menurut kelas 5. Pelajaran seperti ini tidak dapat diberikan secara masal di suatu kelas dengan banyak murid. Setiap anak tentu memerlukan perhatian khusus.

Yang paling sulit adalah menghadapi orang tua anak. Mereka memang sulit menerima keadaan putra-putri mereka. Ibu selalu menghibur mereka dengan mengatakan, bahwa semua anak adalah ciptaan Tuhan. Mereka semua bisa berguna, namun sumbangan mereka kepada masyarakat tidak sama.

Anak-anak ini diciptakan ibarat gelas oleh paberiknya, demikian ibu selalu menjelaskan. "Ada yang besar, yang sedang, dan yang kecil. Yang besar sumbanganpun besar, anak-anak kita adalah gelas-gelas kecil, yang mungkin hanya 
berisikan sedikit, namun ia tetap berguna." Kata-kata ini biasanya membuat orang tua berpikir dan setelah itu mereka lebih mudah memahami keadaan putra-putrinya.

(Sumber di atas diketik kembali dari sebagian aslinya pada tulisan penuturan Pia-Alisyahbana tentang riwayat dari Asih Budi dan perkembangannya dalam buku kenangan "Asih mengasah \& mengasuh Budi").

Sebagian tulisan Pia Alisyahbana tersebut menunjukkan suatu riwayat perkembangan sebuah sekolah khusus bagi tunagrahita. Riwayat perkembangan sekolah itu termasuk unik. Keunikannya terletak pada saat permulaan melayani bagi mereka yang memiliki persoalan tidak mampu mengikuti belajar di sekolah yang biasa atau irama sekolah normal. Persoalan tersebut dipandang oleh perintis sebagai anak-anak yang memerlukan perhatian khusus. Perintis (Ibu Soerjomihardjo) memandang hal itu berdasarkan pengalamannya menjadi guru. Saat permulaan terjadi beberapa siswa yang datang untuk mendapatkan layanan belajar kepada beliau ternyata ada para siswa yang memiliki problema belajar di sekolah biasa. Saat itu, belum banyak yang memperhatikan persoalan bagi anak-anak yang mengalami lemah belajar. Perintis memandang bahwa mereka sebagai anakanak yang terabaikan atau terlupakan, tidak ada yang memperhatikan akan kebutuhan pendidikannya.

Usaha yang dilakukan oleh Ibu Soerjomihardjo (pendiri Asih Budi) untuk melayani mereka dengan memodifikasi kurikulum atau bahan pelajaran yang diberikan di sekolah biasa. Para anak yang bermasalah tersebut diberikan pelajaran sesuai dengan kapasitas kemampuannya, tidak sesuai dengan usia seperti lazimnya di sekolah biasa. Sampai pada fenomena tersebut menunjukkan bahwa pendiri Asih Budi sudah mulai berpikir memberikan "pendidikan khusus" bagi anak-anak yang memiliki kesulitan belajar, yang tidak dapat menyesuaikan dengan irama kelas normal. Pendiri Asih Budi dengan kesabarannya berusaha untuk memberikan bagi setiap anak dengan bahan pelajaran yang disesuaikan dengan kemampuannya. Fenomena tersebut telah menunjukkan pemberian layanan yang diindividualisasikan. Layanan itu sebagai prinsip dasar pada bidang pendidikan khusus.

Pemberian layanan pendidikan khusus dengan memodifikasi bahan pelajaran di sekolah biasa dan menyesuaikan kebutuhan anak secara individual ternyata makin diminati bagi mereka yang sangat membutuhkan. Hal tersebut dengan semakin tambahnya siswa-siswa yang datang ke rumah Ibu Soerjomihardjo. Bertambahnya siswa-siswa yang perlu perhatian khusus menimbulkan pikiran di Ibu Soerjomihardjo untuk membantu pemerintah dengan mendirikan Sekolah Luar Biasa (SLB) di bawah naungan sebuah yayasan. Jadi, suatu layanan pendidikan khusus yang permulaannya diadakan di sebuah garasi di sebuah rumah tinggal semakin berubah untuk dipikirkan menjadi 
sebuah sekolah. Saat permulaan layanan pendidikan khusus tersebut diberikan belum banyak perhatian kepada anak-anak yang mengalami keterlambatan mental atau tunagrahita, maupun mengalami kesulitan belajar di sekolah biasa.

\section{Kausalitas di Wilayah Yogyakarta dan Jawa Tengah}

Yogyakarta dan Jawa Tengah sebagai dua wilayah tempat berdirinya lembaga khusus bagi tunagrahita atas prakarsa pemerintah melalui Kementerian Sosial. Tunagrahita dalam pandangan Kementerian Sosial sebagai penyandang yang menjadi masalah sosial di masyarakat. Oleh karena itu, diperlukan penanganan dengan mendirikan lembaga rehabilitasi. Tahun 1975 merupakan periode realistik pragmatik. Periode ini bercirikan usaha membangun prasarana-prasarana pekerjaan sosial yang dapat dipertanggungjawabkan (Suparlan, 1983: 73). Salah satunya adalah berdirinya Rehabilitasi Cacat Mental di Temanggung sebagai lembaga percontohan tingkat nasional. Jadi, dasar pendirian lembaga tersebut pemerintah bergerak di bidang kesejahteraan sosial.

Lembaga 'Karti Dharma' di Yogyakarta merupakan lembaga yang juga didirikan oleh Departemen Sosial R.I. Lembaga ini hampir memiliki kesamaan, di samping sebagai tempat percontohan rehabilitasi bagi cacat mental, penelitian, dan juga untuk memandirikan tunagrahita. Menurut salah sumber buku dikemukakan sebagai berikut.
“Departemen sosial mempunyai empat lembaga pendidikan dan rehabilitasi Penderita Cacat Mental, yaitu 'Panti Penyantunan Phalamarta' di Cibadak, Panti Penyantunan 'Rahardjo' di Sragen, 'Proyek Percontohan Rehabilitasi Penderita Cacat Mental' di Temanggung, dan Panti Guna 'Karti Dharma' di Yogyakarta. Kedua lembaga tersebut terakhir ada di bawah pimpinan Balai Penelitian Peninjauan (BPPS) di Yogyakarta, sebagai pilot project.

Panti Guna Karti Dharma, mendapatkan nama seperti itu sejak tahun 1964. Tetapi sebagai lembaga pendidikan dan sekaligus sebagai pilot project telah lahir sejak tahun 1958. Pada waktu berdirinya, Panti Guna ini masih merupakan suatu urusan dari suatu seksi, seksi Diagnostik dan Test Kepribadian, dan diberi nama Urusan Orthopaedagogik. Dibandingkan dengan Proyek Percontohan Rehabilitasi Penderita Cacat Mental di Temanggung, Panti Guna ini jauh lebih muda. Proyek Percontohan di Temanggung telah berdiri pada tahun 1904 sebagai suatu lembaga yang memberi pertolongan kepada penderita cacat mental, diurus oleh suatu Yayasan Belanda."

(Sumber tertulis pada buku Pengantar Pendidikan Anak Mental Subnormal yang ditulis YB.

Suparlan)

\section{Pokok Persoalan di Wilayah Jawa Tengah dan Yogyakarta}

Persoalan yang menjadi utama bahwa pendirian lembaga khusus bagi tunagrahita adalah Kementerian Sosial juga memiliki suatu tempat 
yang digunakan untuk percontohan dalam melaksanakan kesejahteraan sosial. Persoalan itu dijawab pada tugas yang dilakukan oleh dua lembaga di Yogyakarta dan Jawa Tengah.

Sebagai proyek penelitian, Panti Guna'Karti Darma' antara lain bertugas sebagai berikut.

- Mempelajari penderita mental subnormal dengan segala permasalahannya yang timbul, untuk kemudian dibuat rencana usaha-susaha lanjutannya.

- Memberikan latihan-latihan kegunaan dan pelajaran kecerdasan (pendidikan formal) dan bersifat individual.

- Memberikan kesempatan kepada penderita mental subnormal untuk mengembangkan kepribadiannya sesuai dengan kemampuannya.

- Mengurangi 'sifat tergantung' yang ada pada diri si anak mental subnormal secara optimal sehingga mereka dapat menyesuaikan diri dengan masyarakatnya.

- Menyediakan fasilitas bagi perguruan tinggi atau pihak lain yang memerlukan untuk praktikum mahasiswa atau pun peninjauan untuk kepentingan ilmu pengetahuan.

Sebagai lembaga pendidikan, Panti Guna Karti Dharma mempunyai tiga bidang kegiatan seperti berikut.

- Pendidikan formal, meliputi membaca, menulis, berhitung (kecakapan uang atau pertokoan) dan lainlain.

- Pendidikan praktis, meliputi prevocational dan vocational training, termasuk pelajaran kerumahtanggaan seperti mencuci, menyeterika, berkebun, menjahit, kerajinan tangan dan sebagainya.

- Penyesuaian sosial, meliputi kepramukaan, bermain, senam, mendengarkan radio dan lain-lain.

Panti Guna Karti Dharma ditiadakan pada tahun 1975, tetapi Panti Guna Wisma Dharma di Temanggung ditingkatkan menjadi Proyek Percontohan Rehabilitasi Penderita Cacat Mental tingkat nasional (Sumber tertulis pada buku Pengantar Pendidikan Anak Mental Subnormal yang ditulis YB. Suparlan).

\section{Kausalitas Berdirinya Lembaga Khusus Tunagrahita di Yogyakarta}

Dasar yang diutamakan adalah mengatasi masalah-masalah belajar dari anak-anak yang gagal belajar di sekolah dasar, dan khusus lembaga 'Panti Asih' memperhatikan anakanak yang belum mendapat perhatian banyak dari masyarakat. Hal tersebut telah dijelaskan dari beberapa fakta historis berdirinya lembaga-lembaga di daerah Yogyakarta dan sekitarnya sebagai berikut.

\section{SLB/C Negeri Yogyakarta}

Pada tahun 1967, di Kotamadya Yogyakarta diadakan Sensus Pendidikan yang dilaksanakan oleh Panitia Kewajiban Belajar Kotamadya Yogyakarta. Dari hasil sensus dapat diketahui adanya anak-anak cacat termasuk anak-anak mental subnormal. Sebagai tindak lanjut kemudian dibentuk Panitia Pembina yang bertugas mempersiapkan berdirinya SLB $/ C$ Negeri, maka berdirilah SLB/C Persiapan Negeri. Sekolah inilah yang kemudian 
benar-benar dinegerikan pada tahun 1968 bersama-sama dengan SGPLB (Sekolah Guru Pendidikan Luar Biasa). Sekolah SLB/C ini juga menjadi sekolah tempat berlatih atau latihan SGPLB.

Pada mulanya, tujuan pendidikan sekolah ini sebagai berikut.

- Memberi bimbingan dan pendidikan anak-anak mental subnormal termasuk slow learners (anak-anak yang lamban belajar).

- Mengembangkan kemampuan anak semaksimal mungkin.

- Menanamkan rasa harga diri dan mendidik untuk berdiri sendiri.

- Mendidik anak mental subnormal agar dapat menyesuaikan diri dalam masyarakat (Sumber tertulis pada buku Pengantar Pendidikan Anak Mental Subnormal yang ditulis YB. Suparlan).

\section{SLB/C 'Dharma Rena Ring Putra' Yogyakarta}

Sekolah swasta berbantuan ini berdiri pada tahun 1963 di bawah Yayasan 'Dharma Rena Ring Putra'. Lembaga swasta berbantuan ini dapat digolongkan sebagai 'usaha swasta netral', yang artinya tidak dihubungkan secara tegas atas dasar agama tertentu. Lembaga-lembaga lain yang netral semacam ini misalnya: SLB/C 'Rindang Kasih' di Magelang, SLB/C Yayasan 'Alpa Kumara Wardana' di Surabaya.

Tujuan didirikannya sekolah untuk anak-anak mental Subnormal Dharma Rena Ring Putra seperti berikut.
- Melatih dan mendidik anak-anak mental subnormal agar dapat self care dan self help.

- Melatih dan mendidik anak-anak mental subnormal agar memiliki keterampilan tertentu sejauh mungkin.

- Melatih dan mendidik anak-anak mental subnormal agar dapat menyesuaikan diri dengan masyarakat (penyesuaian sosial yang optimal). (Sumber tertulis pada buku Pengantar Pendidikan Anak Mental Subnormal yang ditulis YB. Suparlan).

\section{Panti Asih}

- Bahwa setiap manusia, termasuk anak-anak mental subnormal berat mempunyai hak hidup di dunia.

- Bahwa perhatian masyarakat terhadap anak-anak mental subnormal berat masih sangat kurang.

- Bahwa tersedia gedung yang memungkinkan untuk merawat anakanak tersebut, yaitu bekas bangunan sanatorium untuk penderita penyakit TBC di Pakem (Sumber tertulis pada buku Pengantar Pendidikan Anak Mental Subnormal yang ditulis YB. Suparlan)

\section{SPLB Bagian C IKIP YOGYAKARTA}

Sekolah SPLB bagian C IKIP YOGYAKARTA didirikan pada tahun 1968, tepatnya mulai dibuka 4 Maret 1968. Sekolah ini didirikan sebagai usaha untuk melaksanakan suatu penelitian guna menemukan suatu sistem pendidikan yang tepat untuk slow-learners (anak yang mengalami kelambatan dalam belajar/mengikuti pelajaran). Penelitian diketuai oleh 
Drs. Dirto Hadisusanto (dosen FIPIKIP YOGYAKARTA) untuk jangka waktu 5 (lima) tahun.

Anak-anak mengikuti pelajaran di dua lembaga, yaitu di SD I Percobaan IKIP YOGYAKARTA dan SPLB Bagian C IKIP YOGYAKARTA. Untuk pelajaran yang sulit anak diberi pelajaran secara individual di SPLB, sedang untuk pelajaran yang mudah anak diberi pelajaran klasikal di SD (Sumber diriwayatkan oleh salah satu pendiri sekolah, yaitu Sutratinah Tirtonegoro).

\section{Pokok Persoalan Berdirinya Lem- baga Khusus bagi Tunagrahita}

Beberapa persoalan pokok mendirikan lembaga pendidikan tunagrahita di atas menunjukkan bahwa tunagrahita perlu pendidikan khusus dengan bentuk lembaga yang bersifat khusus pula. Bentuk lembaga khusus memungkinkan intensitas program khusus dapat terselenggara terutama bagi anak-anak yang tunagrahita kategori berat seperti di lembaga 'Panti Asih' yang dapat dilihat pada kutipan sumber data berikut.

"Mata pelajaran yang diberikan di Panti Asih adalah: (1) Pendidikan senso-motorik; (2) pendidikan sosial; (3) pendidikan berbicara; (4) pendidikan kepribadian; (5) pendidikan keterampilan; (6) pendidikan orientasi ruang; (7) pendidikan orientasi waktu; (8) membaca, menulis, dan matematika. Di kelas rumah tangga, mata pelajaran itu ditambah dengan pekerjaan ru- mah tangga, menjahit, serta memasak.

Pendidikan senso-motorik, meliputi latihan-latihan pendengaran, perabaan, pengamatan visual, pengertian terhadap susunan atau deretan benda-benda, teka-teki ( $p u z-$ zle), kerjasama (koordinasi) antara mata dan tangan, koordinasi antara mata dan kaki.

Pendidikan sosial pada taraf sederhana, misalnya mengambilkan barang yang jatuh kalau diminta, menyerahkan surat dan lainlain kepada guru, memberi salam selamat pagi, selamat siang dan sebagainya, mengetok pintu jika mau masuk ruang tertentu dan sebagainya.

Pendidikan bahasa meliputi latihan-latihan berbicara, bahasa pasif (misalnya: memberi reaksi kalau dipanggil, melaksanakan perintahperintah sederhana), bahasa aktif (misalnya: menyebut namanya sendiri, alamat rumah, nama sekolahnya dan sebagainya). Pendidikan keterampilan meliputi latihan-latihan keterampilan sehari-hari (misalnya: menyapu lantai, membuang sampah, melap meja, bangku dan sebagainya) dan latihan-latihan yang menjurus kepada kerajinan tangan (misalnya: latihan-latihan memasang monte-monte, menusuk, menyobek kertas, menggunting, merekat, menganyam, bertenun, membuat jelujur di karton atau hard-board sebagai persiapan menjahit dengan tangan maupun mesin). Sedangkan pelajaran memasak meliputi hal mempersiapkan bahan yang akan dimasak hingga menghidangkan makanan di atas meja" (Sumber tertulis pada buku Pengantar Pendidikan Anak 
Mental Subnormal yang ditulis YB. Suparlan).

Pokok persoalan yang masih berlangsung saat sekarang adalah memenuhi kebutuhan khusus tunagrahita agar mampu mandiri di masyarakat. Beberapa data hasil wawancara dari para orang tua ditafsirkan bahwa keberadaan sekolah khusus bagi tunagrahita sebagai lembaga yang membantu perkembangan anak yang menyandang hambatan kategori tunagrahita. Selanjutnya, mereka juga berharap bahwa sekolah mampu membina kemandirian anak-anak tersebut melalui program-programnya. Harapan itu sudah ditangkap oleh kepala sekolah dengan melalui pemikiranpemikiran tentang program sekolah yang fungsional bagi tunagrahita. Program tersebut berorientasi program keterampilan.

\section{PENUTUP}

Hasil penelitian menunjukkan bahwa sejarah lembaga pendidikan khusus bagi tunagrahita berkembang di Jawa dikarenakan mengatasi masalahmasalah belajar siswa-siswa di sekolah dasar. Selanjutnya, problem pokok perlu lembaga pendidikan yang bersifat khusus untuk terselenggaranya program khusus sebagai kebutuhan khusus dari penyandang tunagrahita. Keberlangsungan pokok persoalan kebutuhan lembaga sekolah khusus bagi tunagrahita adalah guna penyelenggaraan program khusus berupa program keterampilan.

\section{UCAPAN TERIMA KASIH}

Terima kasih kami ucapkan kepada Fakultas Ilmu Pendidikan yang telah memberikan dana untuk penelitian mandiri saya, dan setelah saya kemas menjadi suatu artikel juga kami ucapakan terima kasih kepada Redaktur dan Tim Penyunting Jurnal Cakrawala Pendidikan atas penyempurnaan artikel dan kesempatan dimuatnya artikel ini. Terima kasih.

\section{DAFTAR PUSTAKA}

Astati. 2001. Persiapan Pekerjaan Penyandang Tunagrahita. Bandung: Pendawa.

Barnadib, Imam. 1982. Arti dan Metode Sejarah Pendidikan. Yogyakarta: Fakultas Ilmu Pendidikan IKIP Yogyakarta.

Drew, Logan, dan Hardman. 1986. Mental Retardation. ( $3^{\text {th }}$ ed). Columbus: Merril Publishing Company.

Cassirer, E. 1990. Manusia dan Kebudayaan: Sebuah Esei tentang Manusia. (Di Indonesiakan oleh Alois A. Nugroho). Jakarta: Penerbit PT Gramedia.

Smith, M.B., Ittenbach, R.F., \& Patton, J.R. 2002. Mental Retardation. $6^{\text {th }}$ ed. New Jersey: Merrill Prentice Hall.

Sunardi. TT. Kecenderungan dalam Pendidikan Luar Biasa. DEPDIKBUD: Direktorat Jenderal Pendidikan tinggi. 
Suparlan. 1983. Pengantar Pendidikan Anak Mental Subnormal. Yogyakarta:Pustaka Pengarang.

Tilaar, H.A.R. 2005. Manifesto Pendidikan Nasional, Tinjauan dari Perspektif Postmodernisme dan Studi Kultural. Jakarta: Kompas.
Wehmeyer. M.L., et.all. 2008. "The Efficacy of Technology Use by People with Intelectual Disability: A Single-Subject Design Meta-Analysis". Journal of Special Education Technology, 2008, 23, 3. Diunduh dari Proquest Education Journal tanggal 27 April 2011. 